\title{
Phytoplasma presence in carrot seedlings
}

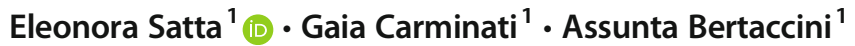

Received: 21 November 2019 / Accepted: 3 February 2020 / Published online: 13 February 2020

(C) Australasian Plant Pathology Society Inc. 2020

\begin{abstract}
Phytoplasmas are cell wall lacking bacteria, insect transmitted, and worldwide infecting carrots with severe epidemics. Molecular tests on up to 4-month-old carrot seedlings from phytoplasma-positive seed batches, carried out under insect proof conditions, indicated that in the early stages of the plant development, the phytoplasma-infected and not water-stressed plants are asymptomatic. The phytoplasma seed transmission could represent a dangerous source of infection.
\end{abstract}

Keywords Growth stage $\cdot$ Molecular detection $\cdot$ PCR/RFLP $\cdot$ Infection percentages

Phytoplasmas are phloem-limited and insect-transmitted bacteria that lack cell walls and that have been associated in carrot (Daucus carota) with redness of leaves, shoot proliferation, and reduced tap roots quality. In Europe, phytoplasmas were often detected in carrot and have been identified as belonging to 16SrI and 16SrXII groups (Font et al. 1999; Duduk et al. 2008). Phytoplasmas were often associated with severe epidemics worldwide, and in several cases in carrot they were associated with other pathogens such as spiroplasmas and Candidatus Liberibacter solanacearum (Cebrián et al. 2010; Satta et al. 2016). Symptoms associated with these bacteria are undistinguishable; therefore, the presence of the diverse pathogens must be demonstrated by molecular tools such as specific DNA amplification. Although phytoplasmas are mainly insect vectored, recent studies demonstrated their transmissibility through seed in some plant species such as alfalfa, tomato, pea, corn, and coconut (Khan et al. 2002; Zwolinska et al. 2010; Calari et al. 2011; Oropeza et al. 2017; Satta et al. 2017, 2019). Symptoms have been observed only in a very low percentage of alfalfa and canola seedlings (Khan et al. 2002; Olivier et al. 2010). It has been shown that phytoplasmas can spread to phloem-related organs, such as the cellular parenchyma (Siller et al. 1987) and to companion cells (Sears and Klomparens 1989); however, the way in which it occurs has not been clarified since the dimensions of these bacteria are

Eleonora Satta

eleonora.satta2@unibo.it

1 Department of Agricultural and Food Sciences, Alma Mater Studiorum - Università di Bologna, 40126 Bologna, BO, Italy greater than those of the plasmodesmata, and at the same time, the presence of specific movement proteins has not been detected (Zambryski 2004). Phytoplasma infections, however, are very common in floral structures, fruits, seeds, and embryos (Bertaccini and Marani 1982; Jiang et al. 2004; Nipah et al. 2007), while the analyses carried out on pollen did not show their presence (Nečas et al. 2008). The recent success in the cultivation of phytoplasmas isolated from maize seedlings deriving from infected mother plants demonstrated also their viability in the colonized seedlings (Satta et al. 2019).

Surveys were carried out to verify the presence of phytoplasmas in seed carrots by Carminati et al. (2019) in which 29 batches of seeds were tested. Of these, 24 were positive for phytoplasmas. A total of 400 seeds from three lots positive for 16SrI phytoplasmas (lot numbers 12, 15, and 18) and one negative lot (lot number 5) were sown in sterile soil in insect-proof greenhouse under controlled conditions and showed 83.3 to 90\% germination irrespective of the phytoplasma presence.

The DNAs from the same seedlings were extracted at the cotyledon stage and three more times later, up to 4-month-old plants with a CTAB method (Angelini et al. 2001) from $1 \mathrm{~g}$ of plant tissue. The DNA was used as template after dilution 1:30 with sterile distilled water (SDW) for the phytoplasma amplification by nested-PCR of the 16S rRNA gene using the R16F2n/R2 (Gundersen and Lee 1996) and R16(I)F1/R1 (Lee et al. 1994). Phytoplasma identification was achieved by RFLP profiles on R16(I)F1/R1 amplicons with TrulI restriction enzyme and direct amplicon sequencing. Phylogenetic analyses were conducted in MEGA6 (Tamura et al. 2013). For results confirmation, amplification was also carried out on the tuf gene using the phytoplasma barcode cocktail primers (Makarova et al. 2012). Phytoplasma strains 
are maintained in collection (Bertaccini 2014), and SDW were employed as positive and negative controls, respectively.

Among the 340 germinated seeds, 200 seedlings of the four lots were tested in batches (14 seedlings per batch) or as single plants at different times after sprouting. At the cotyledon stage (about 3 weeks after sowing), they did not show symptoms; however, phytoplasmas belonging to the ribosomal groups 16SrI and 16SrXII, also in double infection (Table 1), were detected in 5 batches out of 14 tested ( 14 cotyledons per batch) from two phytoplasma positive seed lots (numbers 15 and 18). The 2-month-old seedlings resulted also symptomless, and 4 batches (of 14 plants each), in all the three phytoplasma infected lots, were positive to $16 \mathrm{SrI}$ phytoplasmas $(4 / 14$ batches) (Table 1). Among the 264 -month-old plants singly tested, only one was positive to $16 \mathrm{SrI}$ phytoplasma (lot number 12). Further, 140 seedlings, placed for 3 weeks under water shortage (stressed samples for further phytoplasma seed transmission verification) showed symptoms of root malformation, leaf whitening, and browning (Fig. 1), not present in the watered control plants, and were tested after 3 months: 5 out of the 14 batches (of 8 seedlings per batch) resulted positive to 16 SrI phytoplasmas (Table 2). For the cotyledon and seedling batches, the estimated proportion of a single sample infection $(p)$ was calculated using the maximum likelihood estimator of $p: p=1-\mathrm{Q}^{1 / \mathrm{K}}$, where $\mathrm{Q}$ is the observed fraction of not infected batches and $\mathrm{K}$ is the number of samples per batch (Swallow 1985). The results showed that the $p$ index was 0.03 for cotyledons, 0.02 for the 2-month-old seedlings, and 0.04 for the stressed seedlings. All the tested materials from the phytoplasma negative seed lot number 5 always resulted negative.

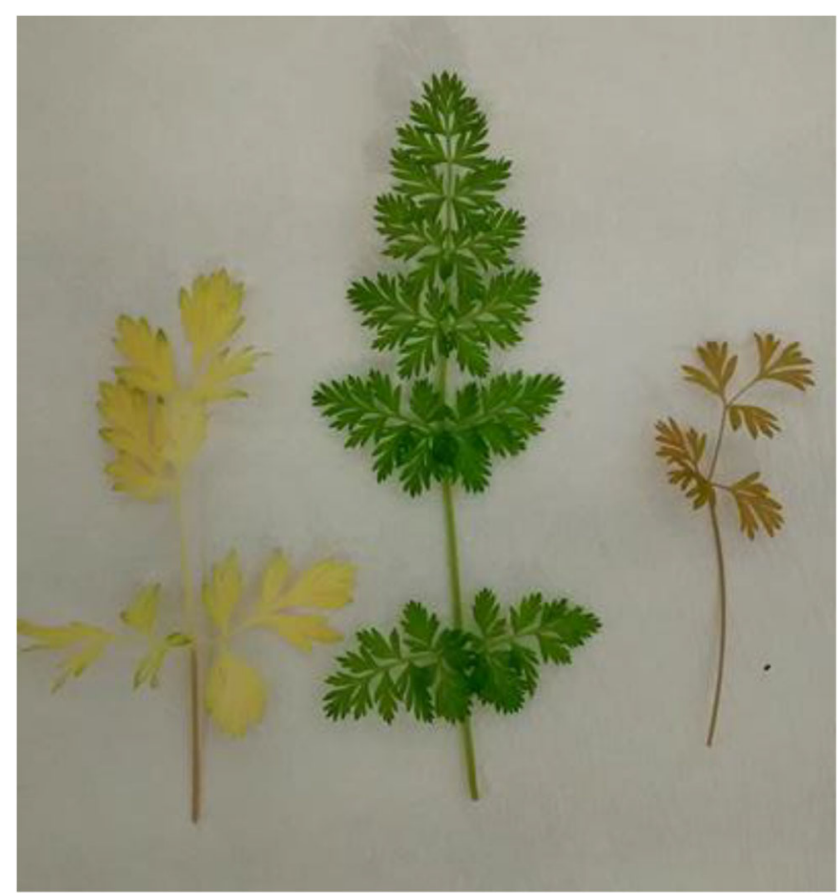

Fig. 1 Seedlings placed in water shortage conditions (stressed samples) and showing symptoms of leaf whitening (left) and browning (right) compared to an asymptomatic leaf from a not stressed carrot seedling (in the middle)

The sequences of all detected phytoplasmas enclosed in 16SrI group (Candidatus Phytoplasma asteris'-related strains) resulted $99 \%$ identical to each other, and two representative sequences among them were deposited in GenBank (accession numbers MN398390 and MN398391). The sequence of the 16SrXII phytoplasma ( $\mathrm{Ca}$. P. solani-related
Table 1 Results of phytoplasma detection in carrot seedlings

\begin{tabular}{|l|l|c|}
\hline $\begin{array}{l}\text { Lot* samples (14 } \\
\text { seedlings per batch) }\end{array}$ & Cotyledons & $\begin{array}{c}\text { 2 month-old } \\
\text { seedlings }\end{array}$ \\
\hline $\mathbf{1 2}$ a & Negative & Negative \\
\hline $\mathbf{1 2}$ b & Negative & 16SrI \\
\hline $\mathbf{1 2}$ c & Negative & Negative \\
\hline $\mathbf{1 2}$ d & Negative & Negative \\
\hline $\mathbf{1 5}$ a & Negative & 16SrI \\
\hline $\mathbf{1 5}$ b & 16 SrI & negative \\
\hline $\mathbf{1 5}$ c & Negative & negative \\
\hline $\mathbf{1 5} \mathbf{d}$ & Negative & negative \\
\hline $\mathbf{1 8}$ a & $16 \mathrm{SrXII}-\mathrm{A}$ & negative \\
\hline $\mathbf{1 8 ~ b}$ & $16 \mathrm{SrI}$ & $16 \mathrm{SrI}$ \\
\hline $\mathbf{1 8} \mathbf{c}$ & $16 \mathrm{SrI}+16 \mathrm{SrXII}-\mathrm{A}$ & $16 \mathrm{SrI}$ \\
\hline $\mathbf{1 8} \mathbf{d}$ & Negative & negative \\
\hline $\mathbf{1 8}$ e & $16 \mathrm{SrI}$ & negative \\
\hline $\mathbf{5}$ a & Negative & Negative \\
\hline $\mathbf{5}$ b & Negative & Negative \\
\hline
\end{tabular}

*Different color indicate different lots. 
Table 2 Results of phytoplasma detection in the 3-month-old stressed carrot seedlings

\begin{tabular}{|c|c|c|}
\hline $\begin{array}{c}\text { Lot* samples (8 } \\
\text { seedling per batch) }\end{array}$ & Symptoms & $\begin{array}{c}\text { Phytoplasma ribosomal } \\
\text { group identified }\end{array}$ \\
\hline 12a & Leaf browning & 16SrI \\
\hline 12b & symptomless & 16SrI \\
\hline 12c & Leaf whitening & Negative \\
\hline 12d & Leaf whitening & Negative \\
\hline 15a & Leaf browning & 16SrI \\
\hline 15b & symptomless & Negative \\
\hline 15c & Leaf whitening & Negative \\
\hline 15d & Leaf whitening & Negative \\
\hline $\mathbf{1 8 a}$ & Leaf browning & Negative \\
\hline $\mathbf{1 8 b}$ & Leaf browning & Negative \\
\hline $\mathbf{1 8 c}$ & Leaf browning & 16SrI \\
\hline $\mathbf{1 8 c}$ & symptomless & Negative \\
\hline $\mathbf{1 8 d}$ & Leaf whitening & Negative \\
\hline $\mathbf{1 8 c}$ & Leaf whitening & 16SrI \\
\hline $\mathbf{5 a}$ & Leaf browning & Negative \\
\hline $\mathbf{5 b}$ & symptomless & Negative \\
\hline $\mathbf{5 c}$ & Leaf whitening & Negative \\
\hline
\end{tabular}

$*$ Different color indicate different lots. strain) detected in single infection in the cotyledon was also deposited in GenBank (accession number MN398389) and clustered with a number of strains classified in the 16SrXIIA subgroup ("stolbur" phytoplasmas). In the phylogenetic tree, the clustering of these sequences confirmed the phytoplasma identification obtained with the RFLP analyses with the R16(I)F1/R1 amplicons (Fig. 2). The phytoplasma presence and identity was confirmed by the amplification of the tuf gene followed by direct sequencing and blasting into the
EPPO-Q-bank database (https://www.eppo.int/ RESOURCES/eppo_databases/eppo_q_bank).

The anomalies and malformations affecting the floral organs and the fruits of plants of several species infected with phytoplasmas allow the production of seeds with reduced vitality (McCoy et al. 1989), quality, and quantity. However, the severity of this phenomenon is related to the time of the infection. Late infections tend to give rise to normal amounts of seed which are however infected (De La Rue et al. 2002) and will therefore give

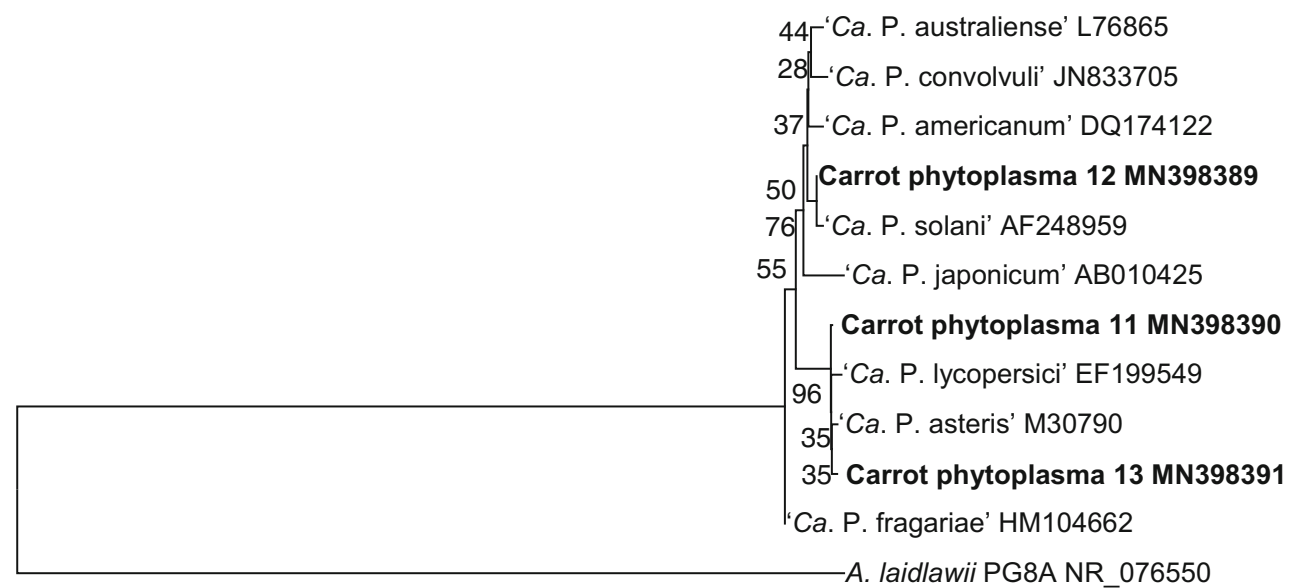

0.1

Fig. 2 The phylogenetic tree was inferred using the neighbor-joining method (Saitou and Nei 1987) enclosing ribosomal gene 16Sr DNA. In bold sequences of strains obtained from carrot seedlings 11, 13, and cotyledon 12. The sequence of Acholeplasma laidlawii strain PG8A was used as out group. On the right GenBank accession numbers, the percentage of replicate trees in which the associated taxa clustered together in the bootstrap test (1000 replicates) is shown next to the branches (Felsenstein 1985). The evolutionary distances were computed using the maximum composite likelihood method (Tamura et al. 2004) and are in the units of the number of base substitutions per site 
the pathogen a greater probability of transmission; on the other hand, an early infection will result in such serious alterations of the mother plant that the seed production is reduced. The recent study on phytoplasma transmission to coconut seedlings (Oropeza et al. 2017) leaves open the possibility that transmission may be less frequent in the natural environment and suggests that the bacteria may be present in the early stages of life of the seedling and be destroyed in subsequent phases by mechanisms of endogenous defense. The results in this work confirm that the phytoplasma presence in seedlings from infected seed batches is asymptomatic, except in the water-stressed seedlings. The 16SrI and 16SrXII phytoplasma seed transmission in carrot could be relevant in field conditions when the possible insect vectors can further enhance their dispersion using the few seedinfected plants as source of inoculum. The phytoplasma seed transmission appears therefore to be relevant and could represent a dangerous source of inoculum. However, more study should be carried out to evaluate the percentage of seed transmission and the economic impact of phytoplasma seedling infection directly in the carrot fields.

\section{References}

Angelini E, Clair D, Borgo M, Bertaccini A, Boudon-Padieu E (2001) "Flavescence dorée" in France and Italy - occurrence of closely related phytoplasma isolates and their near relationship to palatine grapevine yellows and an alder phytoplasma. Vitis 40:79-86

Bertaccini A (2014) http://www.ipwgnet.org/collection. Accessed 27 Oct 2019

Bertaccini A, Marani F (1982) Electron microscopy of two viruses and mycoplasma-like organisms in lilies with deformed flowers. Phytopathol Mediterr 21:8-14

Calari A, Paltrinieri S, Contaldo N, Sakalieva D, Mori N, Duduk B, Bertaccini A (2011) Molecular evidence of phytoplasmas in winter oilseed rape, tomato and corn seedlings. Bull Insectol 64(S):S157-S158

Carminati G, Satta E, Paltrinieri S, Bertaccini A (2019) Simultaneous evaluation of 'Candidatus Phytoplasma' and 'Candidatus Liberibacter solanacearum' seed transmission in carrot. Phytopath Moll 9(1):141-142

Cebrián MC, Villaescusa FJ, Alfaro-Fernández A, Hermoso de Mendoza A, Córdoba-Sellés MC, Jordá C, Ferrándiz JC, Sanjuán S, Font MI (2010) First report of Spiroplasma citri in carrot in Europe. Plant Dis 94(10): 1264

De La Rue SJ, Hopkinson R, Gibb KS (2002) Assessment of Stylosanthes seed yield reduction caused by phytoplasma-associated diseases. Aust J Exp Agr 42(8):1053-1056

Duduk B, Perić P, Marčić D, Drobnjaković T, Picciau L, Alma A, Bertaccini A (2008) Phytoplasmas in carrots: disease and potential vectors in Serbia. Bull Insectol 61:327-331

Felsenstein J (1985) Confidence limits on phylogenies: an approach using the bootstrap. Evol 39:783-791

Font I, Abad P, Albinana M, Espino AI, Dally EL, Davis RE, Jorda C (1999) Amarilleos y enrojecimientos en zanahoria: una enfermedad a diagnostico. Bol San Veg Plagas 25:405-415

Gundersen DE, Lee I-M (1996) Ultrasensitive detection of phytoplasmas by nested-PCR assays using two universal primer pairs. Phytopathol Mediterr 35:114-151

Jiang H, Wei W, Saiki T, Kawakita H, Watanabe K, Sato M (2004) Distribution patterns of mulberry dwarf phytoplasma in reproductive organs, winter buds, and roots of mulberry trees. J Gen Plant Pathol 70:168-173

Khan AJ, Botti S, Paltrinieri S, Al-Subhi AM, Bertaccini A (2002) Phytoplasmas in alfalfa seedlings: infected or contaminated seeds? Abstracts 14th IOM. Vienna, July 07-12:6

Lee I-M, Gundersen DE, Hammond RW, Davis RE (1994) Use of mycoplasma-like organism (MLO) group-specific oligonucleotide primers for nested-PCR assays to detect mixed-MLO infections in a single host plant. Phytopathology 84:559-566

Makarova OV, Contaldo N, Paltrinieri S, Kawube G, Bertaccini A, Nicolaisen M (2012) DNA barcoding for universal identification of 'Candidatus Phytoplasmas' using a fragment of the elongation factor Tu gene. PLoS One 7(12):e52092

McCoy RE, Caudwell A, Chang CJ, Chen TA, Chiykowskyi LN, Cousin MT, Dale de Leeuw GTN, Golino DA, Hackett KJ, Kirkptrick BC, Marwitz R, Petzold H, Shina RH, Sugiura M, Whitcomb RF, Yang IL, Zhu BM, Seemüller E (1989) Plant diseases associated with mycoplasma-like organisms. In: Whitcomb RF, Tully JG (eds) The mycoplasmas, vol 5. Academic, New York, pp 545-640

Nečas T, Mašková V, Krška B (2008) The possibility of ESFY phytoplasma transmission through flowers and seeds. Acta Hortic 781:443-448

Nipah J, Jones P, Hodgetts J, Dickinson M (2007) Detection of phytoplasma DNA in embryos from coconut palms in Ghana, and kernels from maize in Peru. Bull Insectol 60:385-386

Olivier CY, Galka B, Sèguin-Swartz G (2010) Detection of "aster yellows" phytoplasma DNA in seed and seedlings of canola (Brassica napus and B. rapa) and AY strain identification. Can J Plant Pathol 32:298-305

Oropeza C, Cordova I, Puch-Hau C, Castillo R, Chan JL, Sáenz L (2017) Detection of lethal yellowing phytoplasma in coconut plantlets obtained through in vitro germination of zygotic embryos from the seeds of infected palms. Ann Appl Biol 171:28-36

Saitou N, Nei M (1987) The neighbor-joining method: a new method for reconstructing phylogenetic trees. Mol Biol Evol 4:406-425

Satta E, Ramírez AS, Paltrinieri S, Contaldo N, Benito P, Poveda JB, Bertaccini A (2016) Simultaneous detection of mixed 'Candidatus Phytoplasma asteris' and ' $\mathrm{Ca}$. Liberibacter solanacearum' infection in carrot. Phytopathol Mediterr 55(3):401-409

Satta E, Nanni IM, Contaldo N, Collina M, Poveda JB, Ramirez AS, Bertaccini A (2017) General phytoplasma detection by a q-PCR method using mycoplasma primers. Mol Cell Probes 35:1-7

Satta E, Paltrinieri S, Bertaccini A (2019) Phytoplasma transmission by seed. In: Bertaccini A, Weintraub PG, Rao GP, Mori N (eds) Chapter 6Phytoplasmas: plant pathogenic Bacteria-II transmission and Management of Phytoplasma Associated Diseases. Springer, Singapore, pp 131-147

Sears BB, Klomparens KL (1989) Leaf tip cultures of the evening primrose allow stable, aseptic culture of mycoplasma-like organism. Can J Plant Pathol 11:343-348

Siller W, Kuhbandner B, Marwitz R, Petzold H, Seemüller E (1987) Occurrence of mycoplasma-like organisms in parenchyma cells of Cuscuta odorata (Ruiz et Pav.). J Phytopathol 119:147-159

Swallow WH (1985) Group testing for estimating infection rates and probabilities of disease transmission. Phytopathology 7:5882-5889

Tamura K, Nei M, Kumar S (2004) Prospects for inferring very large phylogenies by using the neighbor-joining method. Proc Natl Acad Sci U S A 101:11030-11035

Tamura K, Stecher G, Peterson D, Filipski A, Kumar S (2013) MEGA6: molecular evolutionary genetics analysis version 6.0. Mol Biol Evol 30:2725-2729

Zambryski P (2004) Cell-to-cell transport of proteins and fluorescent tracers via plasmodesmata during plant development. J Cell Biol 164:165-168

Zwolinska A, Krawczyk K, Pospieszny H (2010) First report of "stolbur" phytoplasma infecting pea plants. Abstracts 18th IOM. ChiancianoTerme, 11-16 July 145:152 